\title{
Multisteps Global Kinetic Analysis of MSW Slow Pyrolysis
}

\author{
Dwi Aries Himawanto ${ }^{1}$
}

\begin{abstract}
The goal of this research is to find relationships between single component slow pyrolysis characteristics and mixed components slow pyrolysis characteristics of segregated Municipal Solid Wastes (MSW). The material of this research consists of organic wastes (bamboo wastes and banana leaf wastes) and inorganic wastes (styrofoam wastes and snack wrapping wastes). The materials which used to study were the unprosessing waste. The samples were collected, dried and crushed until passing 20 mesh shieves. Afterwords, pyrolysis was done in a self manufactured macro balance to find the MSW slow pyrolysis characteristics using the thermogravimetry analysis. The 20 gram sample was placed in the furnace whose temperature is increased with $10^{\circ} \mathrm{C} / \mathrm{min}$ heating rate until reached $400^{\circ}$ final temperature and held for 30 minutes before the sample is cooled into room temperature. The results of the research show that the global kinetic method could be used to predict the MSW single component activation energy but it should be modified to calculate the mixed sample activation energy. The predictive activation energy values which calculated based on weighed sum of single component have $18.5 \%$ deviations if compared with experimental result.
\end{abstract}

Keywords - Global kinetic, slow pyrolysis, municipal solid wastes

\begin{abstract}
Tujuan penelitian ini adalah untuk mendapatkan keterkaitan karakteristik slow pyrolysis antara komponen tunggal dan komponen campuran dari sampah kota terseleksi. Bahan yang digunakan dalam penelitian ini terdiri atas sampah organik (sampah bambu dan daun pisang) dan sampah anorganik (sampah styrofoam dan pembungkus kemasan). Dasar pemilihan bahan yang digunakan dalam penelitian ini adalah sampah yang tidak terolah. Pengambilan data diawali dengan pengumpulan bahan baku untuk kemudian dikeringkan dan dihaluskan dan diayak hingga lolos ukuran 20 mesh. Selanjutnya, pirolisis dilakukan dalam sebuah macroblance untuk mencari karakteritik proses slow pyrolysis bahan dengan menggunakan metoda thermogravimetry. Proses pirolisis,dilakukan dengan meletakkan 20 gram bahan baku dalam macrobalance yang suhunya dinaikkan dengan heating rate $10{ }^{\circ} \mathrm{C} /$ menit hingga mecapai temperatur akhir pirolisis $400{ }^{\circ} \mathrm{C}$ untuk kemudian dipertahankan selama 30 menit sebelum didinginkan hingga suhu kamar. Hasil pengambilan dan pengolahan data mengenai perhitungan energi aktivasi menunjukkan bahwa metode global kinetic dapat digunakan untuk menentukan besarnya energi aktivasi komponen tunggal, namun untuk komponen campuran perlu disempurnakan. Pendekatan penghitungan energi aktivasi proses pirolisis sampel campuran dapat didekati dengan weighed sum dari komponen-komponen tunggal penyusunnya, meskipun simpangan yang didapatkan sebesar $18,5 \%$.
\end{abstract}

Kata Kunci-kinetika global, pirolisis lambat, sampah kota

\section{INTRODUCTION}

$\mathrm{T}$ he alternative solution to solve energy provision is to find the abundant energy source reserves. Municipal Solid Wastes (MSW) can be one alternative of energy sources, although the conversion technology from wastes to energy is still intensivelly studied. The prospective technology to convert MSW to energy is pyrolysis, which can convert MSW into gaseous fuel, solid fuel and liquid fuel. The problems which to be faced when pyrolysing MSW are their quantity and their varried components.

The definition of pyrolysis is the solid thermal degradation in a limited oxygen condition, which produce permanent gas, pyrolitic liquid and char [1]. Many researchers have studied the MSW pyrolysis. Pyrolisis of 12 $\mathrm{kg}$ MSW within $400{ }^{\circ} \mathrm{C}-650{ }^{\circ} \mathrm{C}$ temperature range for 4 hours could produced $52.2 \%$ pyrolitic liquid, $25.2 \%$ char and $22.6 \%$ permanent gas [2] .

The packed bed pyrolizer could increase char production $30 \%-100 \%$ compared with the TGA (Thermo Gravimetry Analysis) processes [3]. The study about municipal solid waste slow pyrolysis in a packed bed pyrolizer have done by [4] and continue with the study of product characterization which resulting from the MSW slow pyrolisis [5]. The study of pyrolysis which continued with char combustion

${ }^{1}$ Dwi Aries Himawanto is with Department of Mechanical Engineering, Engineering Faculty, Universitas Sebelas Maret, Surakarta, Indonesia, Email: dwi_ah@uns.ac.id ; dwiarieshimawanto@gmail.com. characteristics of municipal solid waste carried out [6]. Pyrolysis and combustion characteristics of two RDF (Refused Derived Fuel) samples, 6 plastic based samples and 5 wood based samples conducted [7].

One problem in MSW pyrolysis is how to calculate the pyrolysis energy activation because of their multi components condition. This study tried to find the MSW pyrolysis energy activation based on its component decomposistion temperature range.

\section{MATERIAL AND METHODS}

\section{A. Materials}

The materials which used as samples in this study had been collected from final dump site Piyungan Yogyakarta. The samples were bamboo wastes and banana leaf wastes represented organic wastes and inorganic wastes which consisted of styrofoam wastes and snack wrap wastes.

\section{B. Experimental Method}

The first experimental step was collecting the samples and dried samples until the moisture content less than $12 \%$. Afterwords, all of raw materials were crushing and sizing until the particles sizes of samples passed 20 mesh. The main experimantal apparatus was macro balance which adopted from [3] and modified by [9], the schematic configuration of the experimental apparatus can be seen in Figure 1. Pyrolysis was done on 20 grams sample with $100 \mathrm{ml} / \mathrm{min} \mathrm{N}_{2}$ as a swept gas. Heating rate which used in this study was $10^{\circ} \mathrm{C} / \mathrm{min}$ which increased until the sample temperature reached $400{ }^{\circ} \mathrm{C}$ and kept constant for $30 \mathrm{~min}$. 
Thermo Gravimetry Analysis were done to obtain the sample pyrolysis graph. The weight losses data were recorded with A\&D GF-300 Digital Scale while the sample temperatures obtained from the $\mathrm{K}$ type thermocouple which located $2 \mathrm{~cm}$ from the center of sample basket and $1 \mathrm{~cm}$ above the base of sample basket and recorded with ADAM 4018 data acquisitions system. Energy activation calculated based on Arrhenius formulae with first reaction order, which called global kinetics. Table 1 shows the sample composition variations which used in this research.

\section{RESULTS AND DISCUSSION}

The activation energy calculation of single samples pyrolysis process has been carried out by [8]. The calculations showed that the activation energy of the pyrolysis of bamboo was $52.6 \mathrm{~kJ} / \mathrm{mol}$, the banana leaves pyrolysis activation energy was 49.1, snack wrap wastes need a minimum energy of $124.2 \mathrm{~kJ} / \mathrm{mol}$ to pyrolyze and styrofoam waste had activation energy of $118.2 \mathrm{~kJ} / \mathrm{mol}$. The summary of single sample pyrolysis activation energies can be seen in Table 2 .

The results of calculations using the one-step global kinetic analysis can not describe the process of mixed samples thermal decomposition, therefore the mixed samples pyrolysis activation energy calculations using a multi step global kinetic method carried out to link the activation energy of the decomposition with the decomposition temperature of sample main components. Multistep approach has also been done by [1] and [10].

The process of thermal decomposition of samples based biomass cannot be separated from the process of thermal decomposition of their main components, namely hemicellulose, cellulose and lignin. Hemicellulose degraded over a temperature range $498-598 \mathrm{~K}\left(225^{\circ} \mathrm{C}-325^{\circ} \mathrm{C}\right)$ with an activation energy varied between $80-116 \mathrm{~kJ} / \mathrm{mol}$, while cellulose will pyrolysed decomposed gradually in the range $523-773 \mathrm{~K}\left(250^{\circ} \mathrm{C}-500^{\circ} \mathrm{C}\right)$ with activation energy of $18-65$ $\mathrm{kJ} / \mathrm{mol}$ and lignin be decomposed with an activation energy in the temperature range $598-648 \mathrm{~K}\left(325^{\circ} \mathrm{C}-375^{\circ} \mathrm{C}\right)$ which had an activation energy of $195-286 \mathrm{~kJ} / \mathrm{mol}$ [1]. For the pyrolysis process of plastic-based samples, it was found that polystyrene will pyrolysed with activation energies 251.2 $\mathrm{kJ} / \mathrm{mol}$ while low density polyethilene requires activation energy $206.4 \mathrm{~kJ} / \mathrm{mol}[10]$.

In this study, it appears that the pyrolysis thermal decomposition temperature of the sample followed its main components which can be seen in Figure 2 and summarized in Table 3.

The results of activation energy calculation of the mixture samples (i.e $50 \%$ wt organic-50\% wt inorganic) can be seen in Figure 3 and summarized in Table 4. In the table, it can be seen that the mixed samples pyrolysis temperature range was followed the pyrolysis temperature range of a single sample, but the samples pyrolysis had an over-lapping pyrolysis temperature. It might be caused of the sample mixing process gave the synergetic effect or intercomponents reaction which affect the calculation of activation energy pyrolysis. The synergistic effect which occurred at overlapping pyrolysis temperatures must be considered when pyrolyse the mixture materials. Inorganic wastes gave special effect to the mixture material because of the effect of styrofoam component which have nearly $100 \%$ volatile. Greater volatile components in styrofoam wastes make the pyrolysis process occured in lower activation energy. On the contrary, the snack wrap needs the higher activation energy to pyrolyse if compared with the lignocellulosic and styrofoam samples. These different behavior can be explained by the fact that polypropylene soften at about $440^{\circ} \mathrm{C}$ [10] which can be inhibit the evolution of lignocellulosic volatile matter components.

This study performed a calculations which can be use to predict the activation energy of samples pyrolysis. The predictive calculations were based on [7] which stated that the weight lost of the sample mixture during the study is the weighed sum of single component samples and the result could be seen in Figure 4.

The result of calculation showed that the difference between the predicted results with experimental results is $18.5 \%$, where the experimental results gave activation energy of $55.1 \mathrm{~kJ} / \mathrm{mol}$ while the predicted results gave activation energy of $45.1 \mathrm{~kJ} / \mathrm{mol}$ (Figure 5). The difference was presumably because of the intermolecular reactions. In Figures 5, it appears that the predicted results approach the experimental results both in terms of magnitude and temperature range that occured. On the other hand, the predicted results are not able to estimate the relationship between the experimental results of the single components making up the mixture components. This proves that there is a synergetic effect in the sample pyrolysis mixtures that are difficult to predict.

\section{CONCLUSIONS}

From the research conducted, it could be concluded that the calculation results of pyrolysis activation energy showed that the global kinetic methods can be used to determine the activation energy of single components, but for the mixture components need to be modified by using the shifting method based on single components pyrolysis temperature. Calculation results of the mixed samples pyrolysis activation energy based on weighed sum of the components of a single constituent gave the deviations of $18.5 \%$ if compared with experimental results.

\section{ACKNOWLEDGMENT}

This paper was a part of Competitive Research Grant which funded on 2009-2010 by the Directorate General of Higher Education, Ministry of National Education RoI. The author also expresses his gratitude to all of research members (Prof.Dr.Ir. Indarto, DEA., Prof.Dr.Ing.Ir. Harwin Saptoadi, Dr. Eng. Tri Agung Rohmat, B.Eng., M.Eng.) and all of research assistants. 


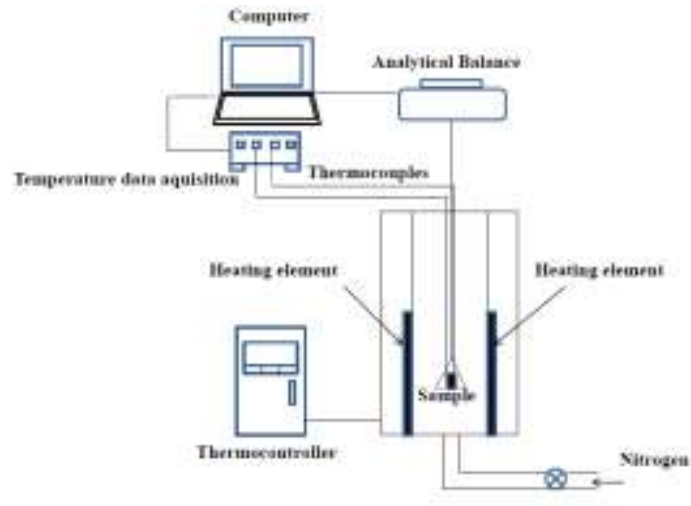

Figure 1. Experimental apparatus

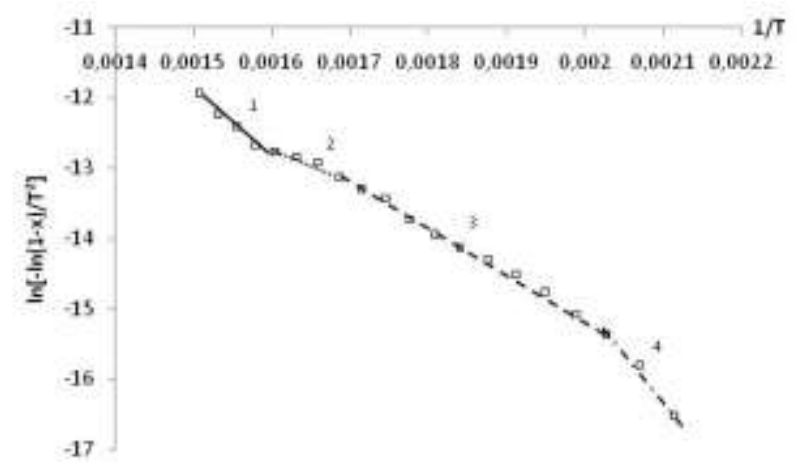

Figure 3. Activation energy of $50 \%$ organic sample based on pyrolysis temperature zone

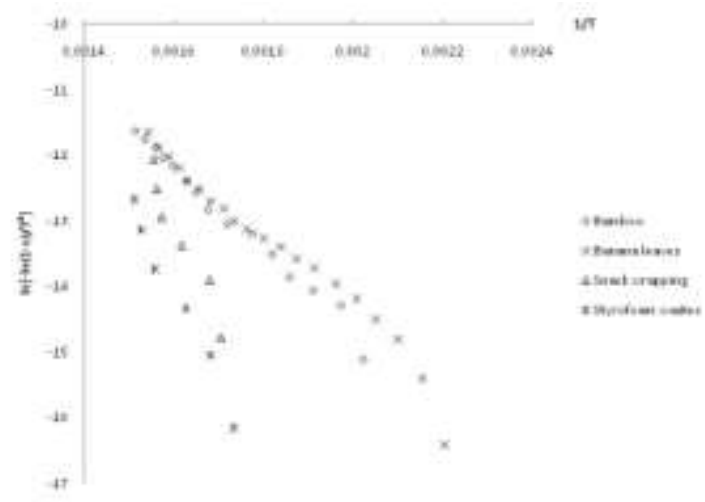

Figure 2. Sample pyrolysis activation energy

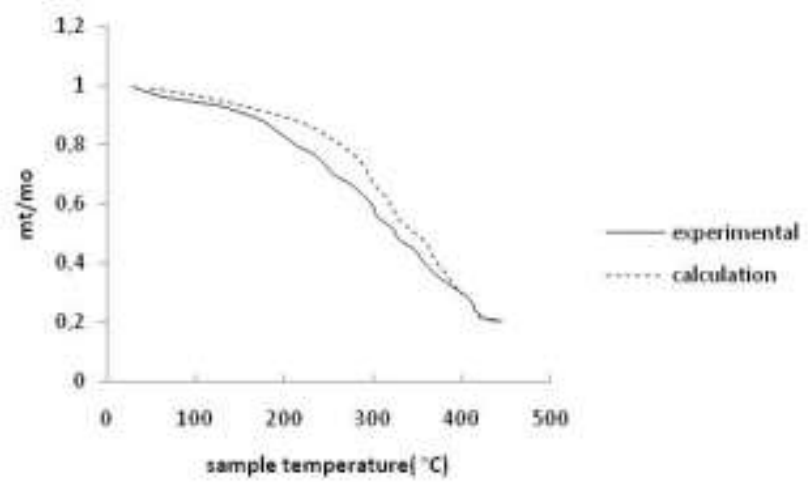

Figure 4. Comparison $\mathrm{mt} / \mathrm{mo}$ graph between experimental result and calculation result for $50 \%$ organic sample pyrolysis

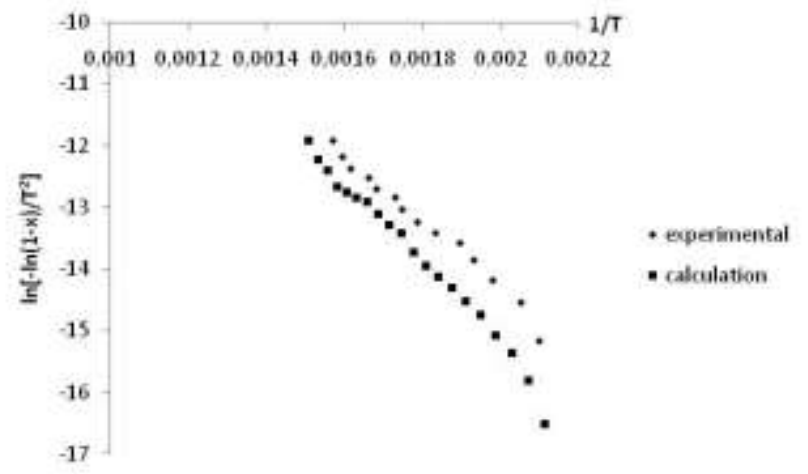

Figure 5. Comparison activation energy between experimental result and calculation result for $50 \%$ organic sample pyrolysis

TABLE 1

MIXED COMPOSITION VARIATIONS

\begin{tabular}{cccccc}
\hline \multirow{2}{*}{ No. } & Variations & $\begin{array}{c}\text { Bamboo } \\
\text { wastes }\end{array}$ & $\begin{array}{c}\text { Banana } \\
\text { leaves wastes }\end{array}$ & $\begin{array}{c}\text { Snack wrap } \\
\text { wastes }\end{array}$ & $\begin{array}{c}\text { Styrofoam } \\
\text { Wrap wastes }\end{array}$ \\
\cline { 3 - 6 } 1. & RDF 1 & 100 & 0 & 0 & 0 \\
2. & RDF 2 & 0 & 100 & 0 & 0 \\
3. & RDF 3 & 0 & 0 & 100 & 0 \\
4. & RDF 4 & 0 & 0 & 0 & 100 \\
5. & RDF 5 & 25 & 25 & 25 & 25 \\
\hline
\end{tabular}


TABLE 2

SumMARY OF Kinetic PARAMETERS FOR Single SAMPLE PyROLYSIS*

\begin{tabular}{ccc}
\multicolumn{2}{c}{ SUMMARY OF KINETIC PARAMETERS FOR SINGLE SAMPLE PYROLYSIS* } \\
\hline Samples & $\begin{array}{c}\text { Activation Energy, E } \\
(\mathrm{kJ} / \mathrm{mol})\end{array}$ & $\begin{array}{c}\text { Pre-exponential Factor, A } \\
\left(\mathrm{min}^{-1}\right)\end{array}$ \\
\hline Bamboo wastes & 52.598 & $3.00 \times 10^{7}$ \\
Banana wastes & 49.063 & $2.79 \times 10^{7}$ \\
Snack wrapping wastes & 124.186 & $8.36 \times 10^{7}$ \\
Styrofoam wastes & 118.208 & $8.37 \times 10^{7}$ \\
\hline *Source $:[8]$ & &
\end{tabular}

TABLE 3

Single Component Pyrolysis Activation Energy Based on Pyrolysis TeMPerature Zone

\begin{tabular}{cccc}
\hline Samples & Zone & $\begin{array}{c}\text { Temperature range } \\
\left({ }^{\circ} \mathrm{C}\right)\end{array}$ & $\begin{array}{c}\text { Activation energy } \\
\mathrm{E}(\mathrm{kJ} / \mathrm{mol})\end{array}$ \\
\hline Bamboo & 1 & $308.0-395.6$ & 60.2 \\
& 2 & $289.5-308.0$ & 22.1 \\
& 3 & $264.6-289.5$ & 67.2 \\
Banana leaves & 4 & $233.5-264.6$ & 31.2 \\
& 5 & $220.9-235.5$ & 136.7 \\
& 2 & $321.1-383.8$ & 61.0 \\
Snack wrap & 3 & $224.7-321.1$ & 36.9 \\
& 4 & $190.8-224.7$ & 67.6 \\
Styrofoam & 2 & $362.5-369.5$ & 170.5 \\
& 1 & $322.2-362.5$ & 416.7 \\
& 2 & $368.6-387.7$ & 74.7 \\
& 3 & $303.4-321.3$ & 192.2 \\
& 3 & & 175.9 \\
\hline
\end{tabular}

TABLE 4

MiXed SAmPle Pyrolysis ACTIVATION EnERgy BASEd on PyRolysis TEMPERATURe Zone

\begin{tabular}{ccc}
\hline Zone & $\begin{array}{c}\text { Temperature range } \\
\left({ }^{\circ} \mathrm{C}\right)\end{array}$ & $\begin{array}{c}\text { Activation energy } \\
\mathrm{E}(\mathrm{kJ} / \mathrm{mol})\end{array}$ \\
\hline 1 & $360-390$ & 83.2 \\
2 & $330-360$ & 27.2 \\
3 & $220-330$ & 53.2 \\
4 & $200-220$ & 111.6 \\
\hline
\end{tabular}

\section{REFERENCES}

[1] C. Di Blasi, "Modeling Chemical and Physical Processes of Wood and Biomass Pyrolisis." Progress in Energy and Combustion Science, vol. 34 , pp. 47-99, 2008.

[2] S.J.Ojolo and A.L.Bamgboye, "Thermochemical Conversion of Municipal Solid Waste to Produce Fuel and Reduce Waste." Agricultural Engineering International : the CIGR Ejournal vol. VII, Manuscript EE 05 006, 2005.

[3] J. Swithenbank, V.N. Sharifi and C. Ryu, Waste Pyrolisis and Generation of Storable Fuel, SUWIC Department of Chemical and Process Engineering, The University of Sheffield, 2005.

[4] Y.B Yang, A.N. Phan, C. Ryu, V. Sharifi and J. Swithenbank, "Mathematical Modelling of Slow Pyrolisis of Segregated Solid Waste in A Packed-Bed Pyroliser", Fuel, vol. 86, pp. 169-180, 2007.

[5] A.N. Phan, C. Ryu, V.N. Sharifi and J. Swithenbank, "Characterisation of Slow Pyrolisis Products from Segregated Wastes for Energy Production", J.Anal.Appl.Pyrolisis, vol. 81, pp. 65-71, 2008.

[6] Z. Cheng, H. Chen,Y. Zhang, P. Hack, and W.P. Pan, "An Application of Thermal Analysis to Household Waste", Journal of ASTM International, vol. 4, no. 1., Paper ID : JAI100523, 2007.

[7] P .Grammelis, P. Basinas, A. Malliopoulou and G. Sakellaropoulos, "Pyrolisis Kinetics and Combustion Characteristics of Waste Recovered Fuels", Fuel, vol. 88, pp. 195-205, 2009.

[8] D.A. Himawanto, Indarto, H. Saptoadi and T.A. Rohmat, "Thermogravimetric Analysis and Global Kinetics of Segregated MSW Pyrolysis." Modern Applied Science, vol. 6, no. 1, pp. 120130, 2012.

[9] D.A. Himawanto, Indarto, H. Saptoadi and T.A. Rohmat, "Thermogravimetric Analysis of Single-Particle RDF Combustion." Modern Applied Science, vol. 7, no. 11, pp. 33-42, 2013.
[10] J. Cai, Y. Wang, L. Zhou, and Q. Huang, "Thermogravimetric Analysis and Kinetic of Coal/Plastic Blends during Co-Pyrolisis in Nitrogen Atmosphere.", Fuel Processing Technology, Vol. 89, pp. 21-27, 2008 